\title{
TIMING OF LH RELEASE AND OVULATION IN 4- AND 5-DAY CYCLIC MICE
}

\author{
AUDREY S. BINGEL \\ Department of Pharmacognosy and Pharmacology, University of Illinois \\ College of Pharmacy, 833 South Wood Street, Chicago, Illinois 60680, U.S.A.
}

\section{(Received 24th September 1973)}

\begin{abstract}
Summary. The time at which ovulation occurred on the morning of oestrus in unmated cyclic mice was investigated; the majority housed with males exhibited 4-day cycles and the majority housed in the absence of males exhibited 5-day cycles. Regardless of housing condition or cycle length, most animals ovulated between 03.00 and 08.00 hours (lights on from 05.00 to 19.00 hours) on the morning of oestrus. The majority of animals injected with barbital at 17.00 hours on the day of pro-oestrus did not ovulate, nor did their ovaries contain stimulated follicles on the morning of 'oestrus.' These results suggest that the critical period for the ovulatory release of LH is similar in 4-day cyclic mice housed in the presence of males and 5-day cyclic mice housed in the absence of males.
\end{abstract}

\section{INTRODUCTION}

Ovulation in singly housed 4- and 5-day cyclic CD-1 mice has been reported to occur predominantly between 01.00 and 05.00 hours on the day of oestrus (lights on from 05.00 to 19.00 hours) (Bingel \& Schwartz, 1969b). In addition, the results of barbital treatment of 5-day mice suggested a critical period for $\mathrm{LH}$ release covering the late afternoon to early evening on the day of pro-oestrus. A late critical period for LH release also seemed probable for 4-day mice because of the apparent similarity of ovulation time for the 4- and 5-day cyclic animals, but the hypothesis could not be tested due to an insufficiency of spontaneously 4-day cyclic mice.

It has recently been shown, however, that housing CD-1 female mice individually with a male, but separated from the male by a steel mesh cage divider, results in the majority of such mice exhibiting 4-day oestrous cycles (Bingel, 1972). Use was made of this technique in the present study, which aimed to compare further the timing of $\mathrm{LH}$ release and ovulation in 4- and 5day cyclic mice, and to determine, if possible (resultant group size permitting), whether any differences might exist between mice housed with males and mice housed without males.

\section{MATERIALS AND METHODS}

Virgin female albino CD-1 mice were obtained from Charles River Mouse 
Farms at 6 weeks of age; the majority were used experimentally when they were between 14 and 19 weeks of age. The animals were housed either individually, without males, or individually with a male but separated from the male by a steel mesh cage divider (Bingel, 1972). Vaginal smears were taken as previously reported (Bingel \& Schwartz, 1969a), beginning 2 weeks after the animals had arrived in the environmentally-controlled laboratory (lights on from 05.00 to 19.00 hours). Mice were subjected to one of the procedures described below after they had exhibited at least two consecutive oestrous cycles of the same length.

\section{Time of cyclic ovulation}

Mice were anaesthetized with ether and subjected to laparotomy (Bingel \& Schwartz, 1969a) (left side only) at 01.00 hours on the morning of expected oestrus, and again at 03.00 hours (right side only). If ovulation had not occurred by the time of the second laparotomy, a third laparotomy was carried out at 05.00 hours. If the oviducts still were not swollen and transparent, indicating that ovulation had not yet occurred, an additional laparotomy was performed at 08.00 hours, and finally, if necessary, at 10.00 hours. At these later three observation times, both oviducts were examined. The results of previous work (Bingel \& Schwartz, 1969b) suggested that when subjected to a 14-hr light/10-hr dark regimen most mice ovulate by 05.00 hours and it was felt that both oviducts should be observed at the later times since one of the ovaries might be deficient in ovulable follicles and/or ovulation might be occurring asynchronously. When swollen transparent oviducts were observed, the mice were killed and the ova from both oviducts were counted. Any animals still negative at 10.00 hours were killed at 'metoestrus' or 'dioestrus (I)'; their ovaries and oviducts were subjected to histological examination.

\section{Time of $L H$ release}

In order to block ovulation, mice were injected intraperitoneally with barbital, $400 \mathrm{mg} / \mathrm{kg}$, at 17.00 hours on the afternoon of pro-oestrus. Control mice were injected with saline. Laparotomy was carried out at 10.00 hours on the day of expected oestrus to determine whether ovulation had occurred. Unilateral ovariectomy was performed on 'blocked' mice and the ovaries and oviducts were preserved for histological study. These animals were subsequently killed at 10.00 hours on the day of 'metoestrus' and the remaining ovary and oviduct were examined histologically for the occurrence of delayed ovulation.

The Tables supplied by Mainland, Herrera \& Sutcliffe (1956) were used in statistical analysis of the data.

\section{RESULTS}

The majority of mice housed with males exhibited 4-day oestrous cycles, and the majority of those housed alone exhibited 5-day cycles. Data obtained for these animals are presented in Tables 1 and 2. Data obtained for the few mice exhibiting 4-day cycles in the absence of males and for the few exhibiting 5-day cycles in the presence of males are presented also, but the small sample size of 
these two groups precludes their statistical comparison with the two larger groups.

\section{Time of cyclic ovulation}

As shown in Table 1, the majority of mice ovulated between 03.00 and 08.00 hours on the day of oestrus. The seventh 4-day mouse, housed in the absence of a male, had not ovulated by 10.00 hours when the right ovary contained large follicles. This mouse was killed at 08.00 hours on the day of 'dioestrus', at which time the remaining ovary contained large follicles that were undergoing atresia. One ovary and one oviduct were removed from each of the two non-ovulating 4-day cyclic mice housed with males at 10.00 hours on the day of 'metoestrus'. The histological appearance suggested (Bingel, 1968) that

Table 1. The time of ovulation in GD-1 mice on the morning of oestrus

\begin{tabular}{c|c|c|c|c|c|c|c}
\hline $\begin{array}{c}\text { Cycle } \\
\text { length }\end{array}$ & $\begin{array}{c}\text { Male } \\
\text { present* }\end{array}$ & $\begin{array}{c}\text { No. of } \\
\text { mice }\end{array}$ & $\begin{array}{c}\text { No. of mice } \\
\text { ovulating }\end{array}$ & $\begin{array}{c}01.00 \\
\text { to } \\
03.00\end{array}$ & $\begin{array}{c}03.00 \\
\text { to } \\
05.00\end{array}$ & $\begin{array}{c}05.00 \\
\text { to } \\
08.00\end{array}$ & $\begin{array}{c}08.00 \\
t o \\
10.00\end{array}$ \\
\hline 4 days & No & 7 & 6 & - & 2 & 4 & - \\
5 days & Yes & 14 & 12 & - & 9 & $3 \dagger$ & - \\
No & 16 & 15 & 2 & $8 \ddagger$ & 5 & - \\
\hline Total & Yes & 1 & 1 & 1 & - & - & - \\
\hline
\end{tabular}

* Females were housed individually or were separa ted from a male by a mesh barrier.

$\dagger$ One of the three was ovulating at 08.00 hours.

$\$$ Two of the eight were ovulating at 05.00 hours.

ovulation might have occurred about $17 \mathrm{hr}$ earlier in these two mice, i.e. on the afternoon of 'oestrus'. The sixteenth 5-day cyclic mouse, housed in the absence of a male, died from an overdose of ether at 05.00 hours; the right ovary contained several stimulated follicles.

\section{Time of $L H$ release}

As shown in Table 2, barbital injected at 17.00 hours on the day of prooestrus effectively blocked ovulation in 4-day cyclic mice housed with males and in 5-day cyclic mice housed without males $(P<0.01$; data for barbital-treated mice compared with those obtained for their respective saline-treated controls). The drug also appeared to be effective in blocking ovulation in 4-day cyclic mice housed in the absence of males.

Six of the nineteen totally 'blocked' mice apparently released LH $24 \mathrm{hr}$ later than normal, as indicated by the finding of stimulated follicles and/or new corpora lutea in their ovaries (and in the latter case, newly ovulated ova in their oviducts) removed on the morning of 'metoestrus'. The release of LH was apparently delayed for only about $12 \mathrm{hr}$, however, in the two mice whose ovaries contained stimulated follicles at 10.00 hours of 'oestrus'. The ovaries of these two mice actually contained follicles that were only slightly stimulated, i.e. the follicles resembled 8-hr preovulatory follicles (Bingel, 1968). The histo- 
Table 2. The effects of barbital or saline administered to CD-1 mice at 17.00 hours on the day of pro-oestrus

\begin{tabular}{|c|c|c|c|c|c|c|}
\hline \multirow{2}{*}{$\begin{array}{l}\text { Cycle } \\
\text { length }\end{array}$} & \multirow{2}{*}{$\underset{\text { present* }}{\text { Male }}$} & \multirow{2}{*}{ Treatment } & \multicolumn{2}{|c|}{$\begin{array}{l}\text { Day of 'oestrus' } \\
\text { (10.00 hours) }\end{array}$} & \multicolumn{2}{|c|}{$\begin{array}{l}\text { Day of 'metoestrus' } \\
\quad(10.00 \text { hours })\end{array}$} \\
\hline & & & $\begin{array}{c}\text { No. ovulating/ } \\
\text { no. injected }\end{array}$ & $\begin{array}{l}\text { No. of } S F+1 \\
\text { no. injected }\end{array}$ & $\begin{array}{l}\text { No. ovulating/ } \\
\text { no. blocked } \ddagger\end{array}$ & $\begin{array}{l}\text { No. of } S F+/ \\
\text { no. blocked }\end{array}$ \\
\hline \multirow[t]{2}{*}{4 days } & No & $\begin{array}{l}\text { Barbital } \\
\text { Saline }\end{array}$ & $\begin{array}{l}0 / 5 \\
4 / 4\end{array}$ & $\underline{0 / 5}$ & $0 / 5$ & $\underline{0 / 5}$ \\
\hline & Yes & $\begin{array}{l}\text { Barbital } \\
\text { Saline }\end{array}$ & $\begin{array}{r}1 \$ / 7 \\
8 / 8\end{array}$ & $\underline{0 / 7}$ & $2 \$ / 6$ & $1 / 6$ \\
\hline \multirow[t]{2}{*}{5 days } & No & $\begin{array}{l}\text { Barbital } \\
\text { Saline }\end{array}$ & $\begin{array}{r}0 / 10 \\
10 / 10\end{array}$ & $29 / 10$ & $\underline{2 / 8}$ & $1 / 8$ \\
\hline & Yes & $\begin{array}{l}\text { Barbital } \\
\text { Saline }\end{array}$ & $1 / 1$ & - & 二 & E \\
\hline
\end{tabular}

* Females were housed individually or separated from a male by a mesh barrier.

$+\mathrm{SF}=$ Stimulated follicles (Bingel \& Schwartz, 1969b) in ovary, but no new corpora lutea.

$\ddagger$ Mice having no new corpora lutea or stimulated follicles in their ovaries at 10.00 hours on the day of 'oestrus'.

$\$$ Ovulation was incomplete in these three mice; their ovaries contained corpora lutea and stimulated follicles.

Tा See text.

logical appearance of the second ovary and oviduct taken at 10.00 hours on the day of 'metoestrus' from these animals resembled that of similar tissues removed $15 \mathrm{hr}$ after ovulation (Bingel, 1968).

\section{DISCUSSION}

The results of this study indicate that in a 14-hr light/10-hr dark environment CD-1 mice with 4-day cycles housed with males and CD-1 mice with 5-day cycles housed without males ovulate at similar times, mainly between 03.00 and 08.00 hours of oestrus. Previously (Bingel \& Schwartz, 1969b), ovulation in 4and 5-day cyclic mice of this strain, housed without males under similar lighting conditions, was reported to occur predominantly between 01.00 and 05.00 hours. Closer comparison of the two studies, however, reveals that there is a large overlap between the results. In the earlier study, but not in the present one, a small proportion of the mice ovulated between 08.30 and 10.30 hours. Furthermore, since in the earlier study no laparotomies were performed at 03.00 hours it is impossible to determine whether more of those animals might have been ovulating just after 01.00 hours or just before 05.00 hours. The effectiveness of barbital in blocking ovulation in both studies, when administered at 17.00 hours on the day of pro-oestrus, $12 \mathrm{hr}$ before the mid-point of the peak ovulation time found in the present study, provides further evidence to suggest that the ovulation time for the mice in the two studies was probably similar.

The results of the present study also support the hypothesis that 4- and 5-day cyclic mice have a late critical period for $\mathrm{LH}$ release. This observation contrasts with that reported for the rat; 5-day cyclic rats have been shown to have a longer and later critical period for LH release than have the 4-day cyclic animals 
(Hoffmann \& Schwartz, 1965). Both 4- and 5-day cyclic mice appear to be more comparable in this respect to the 5-day cyclic rat.

Finally, the results of this study also provide further insight into the possible cause of the irregularity (Bingel, 1972) of the mouse oestrous cycle. It is suggested (A. S. Bingel, B. G. Mann and W. L. Talley, unpublished observations) that one possible reason may be that the mouse may be much more susceptible than the rat to cycle disruption by environmental perturbances. Observations made in the present study suggest that the mouse may be less strongly influenced than the rat by the 24-hr 'clock' mechanism that controls the ovulatory surge of LH (Hoffmann \& Schwartz, 1965). Studies by Bingel \& Schwartz (1969c) and Hoffmann \& Schwartz (1965) indicated that, in the mouse, the time of the post-partum ovulatory surge of $\mathrm{LH}$ was less strictly related to the time of day than it was in the rat. In reviewing the literature, Hoffmann \& Schwartz (1965) pointed out that manipulations that advanced or delayed $\mathrm{LH}$ release and ovulation in the rat did so by a full $24 \mathrm{hr}$. A barbital-induced 24-hr delay in LH release and ovulation has also been demonstrated in the mouse in the present study and previously by Bingel \& Schwartz (1969b, c). In two of the mice in the present study however, a delay of only about $12 \mathrm{hr}$ apparently occurred, suggesting that in this species the critical period may not be unalterably associated with the late afternoon and early evening. Okamoto (1970) also showed that ovulation in IVCS mice subjected to a 14-hr light/10-hr dark regimen could be delayed for short periods of time by repeated injections of Nembutal administered on the afternoon and evening of pro-oestrus; if the last injection was given at 21.00 hours (anaesthesia having been maintained from 13.00 hours), ovulation occurred at about 11.00 hours on the day of oestrus instead of at about 03.00 hours. If the last injection was given at 23.00 hours, however, ovulation was delayed a full $24 \mathrm{hr}$. Observations made in the present study have also suggested that a small number of untreated cyclic mice may be able to release $\mathrm{LH}$ at a time other than during the late afternoon and early evening. The "four and a half day" cycle (Shirley, Wolinsky \& Schwartz, 1968), thought to be impossible for the rat to exhibit because of the importance of the 'clock', appears to be possible at least for some mice. Nevertheless, since such an observation appears to be extremely rare, it is tempting to speculate that the absence of a strongly influential 'clock' may contribute more often to the occurrence of irregular (Bingel, 1972), and probably anovulatory, cycles.

\section{AGKNOWLEDGMENTS}

The author wishes to thank Mr Judge A. Harris and Mr Marshall P. Goldberg for preparing some of the tissues that were studied histologically. This study was supported in part by $\mathrm{I} / \mathrm{C}$ Graduate Research Grant 2-41-35-30-3-08, awarded to the author by the University of Illinois Graduate College.

\section{REFERENCES}

BiNGEL, A. S. (1968) The timing of cyclic and post-partum ovulation in the mouse. Ph.D. thesis, University of Illinois, Ghicago. 
Bingel, A. S. (1972) Estrous cyclicity in mice housed in the presence or absence of males. Proc. Soc. exp. Biol. Med. 139, 515.

Bingel, A. S. \& Schwartz, N. B. (1969a) Pituitary LH content and reproductive tract changes during the mouse oestrous cycle. F. Reprod. Fert. 19, 215.

Bingel, A. S. \& Schwartz, N. B. (1969b) Timing of LH release and ovulation in the cyclic mouse. J. Reprod. Fert. 19, 223.

Bingel, A. S. \& SchwarTz, N. B. (1969c) Timing of LH release and ovulation in the post partum mouse. 7. Reprod. Fert. 19, 231.

Hoffman,, J. G. \& Schwartz, N. B. (1965) Timing of post-partum ovulation in the rat. Endocrinology, 76,620 .

Mainland, D., Herrera, L. \& Sutcliffe, M. I. (1956) Tables for Use with Binomial Samples, pp. 10, 15. New York University College of Medicine, New York.

Окамото, M. T. (1970) A study of release of ovulating hormone in IVGS strain mice. I. Delay in ovulation caused by Nembutal. Fap. F. Anim. Reprod. 16, 52.

Shirley, B., Wolinsky, J. \& Schwartz, N. B. (1968) Effects of a single injection of an estrogen antagonist on the estrous cycle of the rat. Endocrinology, 82, 959. 